
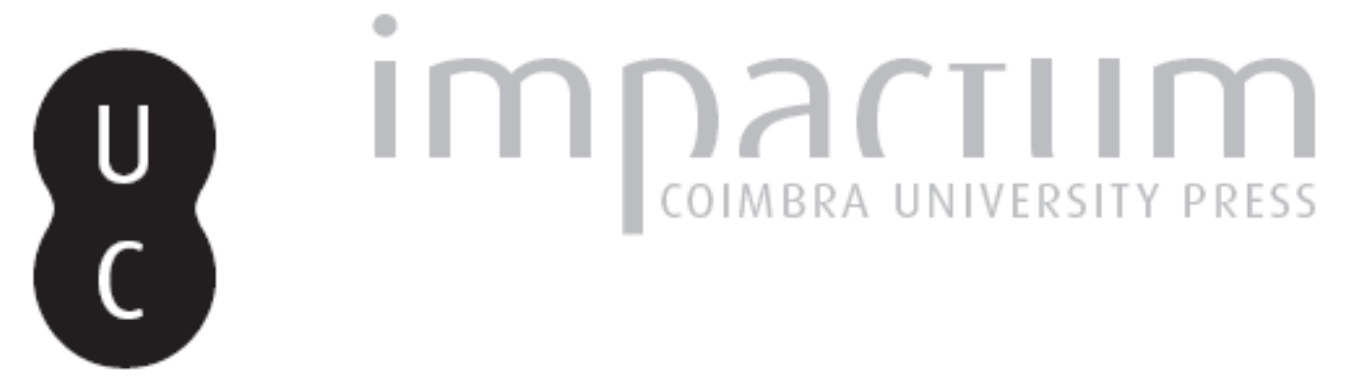

\title{
Símbolos e ícones da nação: exame comparativo entre os símbolos da "Mensagem" de Fernando Pessoa e os símbolos figurados na Faculdade de Letras da Universidade de Coimbra
}
Autor(es):
Duarte, Marco Daniel

Publicado por: Imprensa da Universidade de Coimbra

URL

persistente:

URl:http://hdl.handle.net/10316.2/45011

DOI:

DOI:https://doi.org/10.14195/0870-4147_38_16

\section{Accessed : $\quad$ 26-Apr-2023 16:29:36}

A navegação consulta e descarregamento dos títulos inseridos nas Bibliotecas Digitais UC Digitalis, UC Pombalina e UC Impactum, pressupõem a aceitação plena e sem reservas dos Termos e Condições de Uso destas Bibliotecas Digitais, disponíveis em https://digitalis.uc.pt/pt-pt/termos.

Conforme exposto nos referidos Termos e Condições de Uso, o descarregamento de títulos de acesso restrito requer uma licença válida de autorização devendo o utilizador aceder ao(s) documento(s) a partir de um endereço de IP da instituição detentora da supramencionada licença.

Ao utilizador é apenas permitido o descarregamento para uso pessoal, pelo que o emprego do(s) título(s) descarregado(s) para outro fim, designadamente comercial, carece de autorização do respetivo autor ou editor da obra.

Na medida em que todas as obras da UC Digitalis se encontram protegidas pelo Código do Direito de Autor e Direitos Conexos e demais legislação aplicável, toda a cópia, parcial ou total, deste documento, nos casos em que é legalmente admitida, deverá conter ou fazer-se acompanhar por este aviso. 

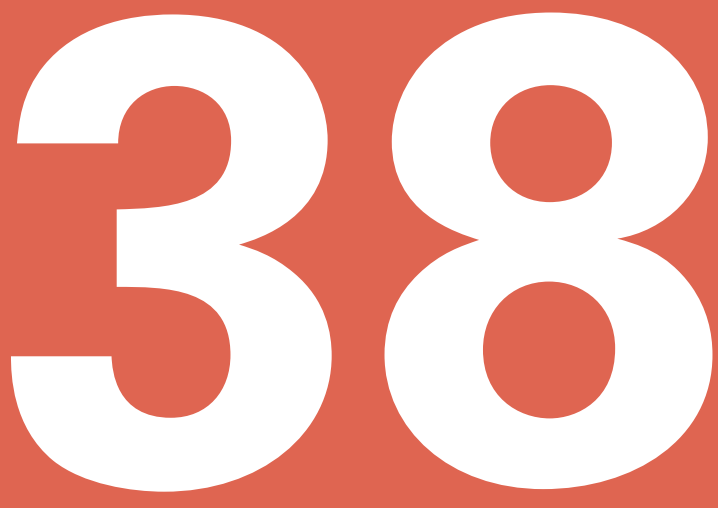

\section{Revista Portuguesa de História}

Faculdade de Letras da Universidade de Coimbra Instituto de História Económica e Social

Coimbra 08 
Revista Portuguesa de História

t. XXXVIII (2006)

pp. 437-464

\title{
Símbolos e Ícones da Nação. Exame comparativo entre os símbolos da "Mensagem" de Fernando Pessoa e os símbolos figurados na Faculdade de Letras da Universidade de Coimbra
}

\author{
Marco Daniel Duarte \\ Investigador \\ Doutorando em História da Arte - Faculdade de Letras da Universidade de Coimbra
}

Observada a história portuguesa em linha diacrónica, podem procurar-se nela momentos diversos em que os símbolos pátrios, urdidos através dos cânones das obras de arte, se viram convocados para servirem, por um lado, ideais estéticos, mas, também, não raras vezes, ideológicos e políticos. Apenas para apontarmos exemplos muito estudados, poderíamos fixar-nos na campanha nacionalista que, nos últimos anos de Oitocentos, esteve subjacente aos ideais republicanos; poderíamos lembrar-nos de como ela esteve alicerçada em símbolos que ajudariam à doutrinação de importantes franjas da sociedade e levariam, em conexão com outras estratégias, obviamente, à instituição da República, sistema político e ideológico que logo seria figurado de forma icónica envolta de símbolos, personificações e alegorias ${ }^{1}$. Se continuássemos a observar o período

1 Por serem questões muito estudadas pela historiografia, estas matérias encontram-se já sintetizadas em obras gerais de consulta e por esta razão pragmática as indicamos. Para a última década do século XIX, veja-se o capítulo "O Estado e o patriotismo" de Rui RAmos, em A Segunda Fundação (1890-1926), sexto volume de História de Portugal, direcção de José MATTOso, p. 69 e seguintes. Na mesma obra, para os anos "post" Cinco de Outubro, veja-se a parte "O Nascimento de uma Nação", mormente nas páginas correspondentes a "Do Patriotismo ao Nacionalismo" (p. 567 e 568). Para um estudo mais refinado, veja-se a obra de Fernando CATroga, O republi- 
histórico subsequente à Primeira República, mais nos aperceberíamos de que, com efeito, a governança ideológica se mune de símbolos e os chama a si para, através deles, fazer transmitir determinados ideais. Com efeito, nas décadas do Estado Novo (todavia com uma argumentação doutrinal diversa da do contexto republicano $)^{2}$, a campanha nacionalista prolongava-se, tendo os ideais pátrios continuado a sustentar o discurso político-ideológico, adquirindo este discurso, inclusivamente, contornos ainda mais vincados que os que estavam no substrato dos programas do republicanismo. Nestes contextos históricos (Primeira República e Estado Novo, aqui apontados meramente como exemplificativos, por serem, neste pequeno ensaio, balizas cronológicas próximas das obras em estudo), os símbolos - materializados na imagem plástica ou na imagem verbal - foram elementos importantes que concorreram para legitimação de ideias e, ainda mais, para a transmissão dessas ideias, auferindo estas uma justificação mais penetrante e segura junto de quem interessava catequizar.

Como deixamos intuir, o recurso ao símbolo é uma estratégia antiga, presente em todas as sociedades organizadas que tenham consciência do poder do objecto simbólico e dos efeitos que esse objecto produz no indivíduo e na comunidade. Os criadores de arte, mais ou menos adentro das estéticas vigentes, mais ou menos afastados da manipulação política e mais inocentes ou mais inconscientes do valor dos símbolos, recorrem a eles com grande frequência por neles reconhecerem superior valor de expressividade e de comunicabilidade. Muitas vezes fazem-no segundo planos que lhes são propostos, outras vezes, que certamente não serão raras, apenas por quererem criar obra de arte assente em linguagem simbólica. Neste último caso, talvez até mais que no primeiro, terão consciência das suas escolhas e opções simbólicas e revelam um conhecimento profundo das potencialidades dos símbolos, garantindo para a sua

canismo em Portugal: da formação ao 5 de Outubro de 1910, Lisboa, Editorial Notícias, 2000 (2. ${ }^{a}$ edição). Veja-se, ainda, sobre a evolução das movimentações republicanas no advento da implantação da República, Amadeu Carvalho Homem, A Propaganda Republicana. 1870-1910, Coimbra, s. e., 1990.

2 Dos muitos estudos que se poderiam apresentar, pelas mesmas razões apontadas na nota anterior, indicamos, de Jorge Ramos do Ó, Salazarismo e Cultura (p. 387-454), nomeadamente as p. 421 e seguintes, em Fernando Rosas (coordenação), Portugal e o Estado Novo (1930-1960), volume XII de Joel SERrão e A. H. de Oliveira MArques (direcção), Nova História de Portugal, Lisboa, Editorial Presença, 1990. De grande utilidade, por nele se analisarem as comemorações oficiais, plenas de simbologia, do tempo do final da Monarquia, da Primeira República e do Estado Novo, é o estudo de Maria Isabel Jõ̃o, Memória e Império. Comemorações em Portugal (1980-1960), Lisboa, Fundação Calouste Gulbenkian, Fundação para a Ciência e a Tecnologia, 2002. Por esta tese doutoral se pode verificar como as práticas, os ritos, a iconografia e os discursos produzidos em ordem às várias comemorações estavam prenhes de símbolos. 
obra uma fina erudição, como é o caso dos autores das obras que neste estudo analisamos ${ }^{3}$.

Com o intuito de perceber as suas significações mais epidérmicas ou mais fundas, aquilataremos a obra de Fernando Pessoa saída dos prelos em 1934 e, entre outras criações artísticas plásticas da Faculdade de Letras da Universidade de Coimbra, a pintura de um dos painéis do seu vestíbulo principal, pintado em 1951 por Severo Portela Júnior ${ }^{4}$. Com efeito, ao encontrarmos em "Mensagem" e em "Glorificação do Génio Português" composições, fundamentalmente, alegóricas (constituídas por símbolos), parece-nos legítima a comparação.

Muito estudada sob variados pontos de vista, embora nem sempre dos mais cientificamente $\operatorname{acertados}^{5}$, a sem dúvida mais emblemática composição poética de Fernando Pessoa é constituída, do seu início ao seu termo, essencialmente, por símbolos. Efectivamente, cada um dos quarenta e quatro poemas que constituem "Mensagem" é, em primeira análise, o desenvolvimento em expressão poética do pensamento do autor sobre uma figura ou situação histórica que é tomada, antes do mais, como simbólica.

3 O exame que aqui propomos é, de variados pontos de vista, arriscado, pois pode ser censurável, por exemplo, na medida em que, como se verá, se procede a uma comparação de obras artísticas cuja valoração estética é muito diversa. No entanto, o que ousamos ensaiar é apenas a laboração de um exame muito grato ao iconógrafo-iconólogo: perceber de que modo dois criadores artísticos se servem dos mesmos elementos de significação simbólica para fabricarem obra de arte. $\mathrm{O}$ estudo que traçamos revela-se ainda mais digno de interesse, porque nele se comparam, inclusivamente, obras de campos artísticos diferentes: uma obra literária e uma obra pictórica. Assim, tentaremos averiguar até que ponto expressões estéticas diversas reproduzem, nos seus conteúdos e sentidos mais imediatos ou mais profundos, o pensamento de um determinado viver histórico.

4 Fizemos já esta comparação, de forma mais breve, no estudo Faculdade de Letras da Universidade de Coimbra. Ícone do Poder. Ensaio Iconológico da Imagética do Estado Novo, Coimbra, Câmara Municipal de Coimbra, 2003, p. 120 e seguintes.

5 Disso faz queixa Teresa Rita LoPEs, por exemplo, na entrada Fernando António Nogueira Pessoa, em Fernando Rosas, J. M. Brandão de Brito (direcção), "Dicionário de História do Estado Novo", Venda Nova, Bertrand Editora, 1996, vol. II, p. 720 a 723. De forma clarividente, a autora escreve: «o pendor nacionalista, que [Fernando Pessoa] reconhece como uma constante do seu carácter e da sua obra - e anima Mensagem, seu único livro a valer por ele publicado a 1 de Dezembro de 1934 -, é indissociável da sua militância como liberal». A autora diz ainda que Fernando Pessoa liberal «se insurgiu contra João Franco, Salazar, Hitler, Mussolini e contra toda a forma de fanatismo e tirania»; p. 722 do artigo incluso no citado dicionário. Uma parte substancial da base documental para esta síntese e que, nomeadamente em relação a "Mensagem", veio elucidar sobre as não coincidências entre o pensamento pessoano e o pensamento estadonovista encontra-se publicada e abordada em Teresa Rita Lopes (coordenação), Pessoa Inédito, Lisboa, Livros Horizonte, 1993. Neste contexto é ainda pertinente a obra de João Medina, Salazar, Hitler e Franco. Estudos sobre Salazar e a ditadura, Lisboa, Livros Horizonte, 2000. 
Ainda que subsistam muitos motivos de abordagem e novas formas de interpretação de "Mensagem", de Fernando Pessoa, parece ser unânime que o poeta arquitectou o poema de uma forma muito pensada e que os seus sentidos muito apurados, não raramente, mas quase sempre, muito requintados, resultam de um conhecimento profundo dos símbolos da nação lusa para através deles formar, nas palavras já escritas que subscrevemos, «o moderno metapoema português ${ }^{6}$. Fazendo uso destes símbolos como estratégia, todo o poema "Mensagem" assenta em simbolismo muito chegado ao patamar do celebrativo e do religioso, mesmo doxológico, pois faz evocação de símbolos pátrios tirados do passado (concretização anamnética) para os convocar para o presente, colocando neles valores de acção (concretização laudativa, isto é, doxológica $)^{7}$ que, como veremos, será estratégia usada pela figuração pictórica do Estado Novo.

\section{un}

Não querendo comparar a qualidade estética pessoana com a do pintor dos painéis do primeiro grande edifício do complexo arquitectónico estadonovista da Universidade de Coimbra (o edifício da Faculdade de Letras ${ }^{8}$ ), faremos um exercício de análise almejando perscrutar os símbolos comuns a uma e a outra obra de arte. Antes, porém, passemos revista, ainda que de maneira sumária, ao processo que levou à composição pictórica de Severo Portela Júnior.

Em 28 de Abril de 1949, o director da Faculdade de Letras da Universidade de Coimbra, Aristides de Amorim Girão, responde a uma carta de Luís Cristino da Silva, arquitecto da Comissão Administrativa do Plano de Obras da Cidade Universitária de Coimbra (comissão conhecida pela sigla formada pelas iniciais da sua titulatura: CAPOCUC), comunicando que a Faculdade já se havia debruçado acerca das matérias a figurar no seu edifício e anexando o parecer de um dos professores da casa sobre o que deveria ser representado. Manuel Lopes de Almeida, professor da Faculdade de Letras e director da Biblioteca da

6 Tomamos a expressão de Maria Irene Ramalho S. SANTos. A fundamentação argumentada desta expressão encontra-se no estudo A Hora do Poeta: o "Hyperion" de Keats na "Mensagem" de Pessoa, em "Revista da Universidade de Coimbra”, Coimbra, 1992, vol. XXXVII, p. 389-399. A autora utiliza a referida expressão na p. 398.

7 A utilização que fazemos de vocabulário típico da ciência litúrgica é uma demonstração de que "Mensagem" se encontra carregada de significações da esfera do sagrado.

8 Em rigor, o primeiro edifício a ser inaugurado é o do Arquivo da Universidade, em 1948.09.18, mas é o da Faculdade de Letras o que mais impacto terá na construção da "alameda" dedicada ao Estudo. 
Universidade, era de opinião, segundo as palavras do director da Faculdade que tomava também como descritivas do seu pensamento, «que um dos painéis devia ser exclusivamente dedicado à glorificação do génio português»»?

Através do documento da lavra de Lopes de Almeida, que Amorim Girão recebeu e anexou à epístola de resposta ao arquitecto Cristino da Silva, poderemos perceber, para além das escolhas iconográficas para o painel, quais seriam as linhas que deveriam nortear uma Escola, neste caso, a Faculdade de Letras. O lente afirmava «que numa escola portuguesa, e sobretudo numa Faculdade de Letras» a «função primordial e específica é mais do que tudo educativa, embora simultaneamente de preparação pedagógica $»^{10}$. Embora sem completa certeza do pleno significado que as expressões «educativa»e «preparação pedagógica» tinham para o docente, pensamos que podemos entender a primeira como significadora das valências abrangentes de formação cívica do indivíduo adentro de uma sociedade e a segunda mais relacionada com a formação dos conhecimentos científicos apreendidos nos bancos das salas de aulas. Será motivo de análise que a ênfase tenha sido posta, acima do mais, antes da formação de nível científico, na formação educativa, dos valores. Esta opinião, embora tirada de um contexto em que o professor apenas reflectiu neste assunto de forma marginal (e talvez nem tanto assim...) é deveras importante para o conhecimento do sistema educativo no Estado Novo ${ }^{11}$,

9 É este o texto em que pela primeira vez aparece a expressão que intitula o mural da Faculdade de Letras: "Glorificação do Génio Português". AUC [Arquivo da Universidade de Coimbra], CAPOCUC [Comissão Administrativa do Plano de Obras da Cidade Universitária de Coimbra], Pasta 275, Pintura a fresco das paredes do átrio da Faculdade de Letras. O documento foi publicado no volume de anexos da dissertação de doutoramento de Nuno RosmaninHo, O Poder da Arte. O Estado Novo e a Cidade Universitária de Coimbra, Coimbra, Faculdade de Letras da Universidade de Coimbra, 2001, 2 volumes, policopiada, p. 269-270 do referido volume de anexos. A edição deste estudo, com o mesmo título (Coimbra, Imprensa da Universidade, 2006), publicou também o documento a que aludimos nas p. 372-375. Como nesta edição não se publica o vasto corpus documental que compõe o referido volume de anexos, sempre que aludirmos a algum documento dado a conhecer por ocasião desta dissertação, remeteremos para esse corpus publicado em 2001.

${ }^{10}$ Parecer de Manuel Lopes de Almeida sobre as figurações a pintar no átrio da Faculdade de Letras da Universidade de Coimbra; AUC, CAPOCUC, Pasta 275, Pintura a fresco das paredes do átrio da Faculdade de Letras, também inserido por Nuno RosmANINHO no volume documental de $O$ Poder da Arte..., p. 270.

${ }^{11}$ Vejam-se, na obra de coordenação de Maria Cândida ProençA, "Um Século de Ensino da História”, Lisboa, Edições Colibri, Instituto de História Contemporânea da Faculdade de Ciências Sociais e Humanas da Universidade Nova de Lisboa, 2001, os estudos de Luís Reis Torgal, Ensino da História e Ideologia (p. 23-40) e de Maria Manuela CARvalho, O Ensino da História no Estado Novo (p. 75-91). 
pois não se trata apenas da opinião de um professor universitário (o que já por si lhe conferiria carácter de importância), mas também porque se trata da opinião de um homem que desempenhou altos cargos nesse sistema educativo: Manuel Lopes de Almeida, para além de lente da Faculdade de Letras e de director da Biblioteca Geral da Universidade de Coimbra, foi Director-geral do Ensino Superior e das Belas-Artes (em 1940), Subsecretário de Estado da Educação Nacional (desde 1940 a 1946) e, entre Maio de 1961 e Dezembro de 1962, foi Ministro da Educação Nacional ${ }^{12}$.

O génio nacional evocado no documento de Manuel Lopes de Almeida seria, com efeito, a temática que seguiria por diante e curiosas e dignas de estudo são as formas figuradas por se adequarem, verdadeiramente, às formas recomendadas. Tirando do campo semântico da arte do cristianismo medieval a palavra latina "exempla" (que a Igreja Católica desde os primevos tempos utiliza em referência aos mártires, primeiramente, e, depois, aos santos cujas vidas devem pautar as dos fiéis), o lente escrevia que num «desses painéis devia oferecer-se à contemplação dos seus escolares como exempla a imagem daqueles que no decorrer dos oito séculos de vida histórica de Portugal exprimiram no pensamento e na acção o próprio génio português $\rangle^{13}$. Sem avançarmos, ainda, pelas comparações mais evidentes, apenas para comprovarmos da oportunidade deste exercício, apercebamo-nos de que a palavra "exemplo", com este sentido forte, já havia sido usada pelo o punho criador de Fernando Pessoa, aplicando-a ao primeiro rei de Portugal. Também aí se diz, com efeito, que este monarca era «o exemplo inteiro» ${ }^{14}$.

${ }_{12}$ Veja-se a pequena nota biográfica da autoria de Maria Cândida ProEnçA, Manuel Lopes de Almeida, em "Dicionário de História do Estado Novo", supracitado, vol. I, p. 39. Aqui se faz referência à sua acção política em momentos importantes da história do Estado Novo, nomeadamente, à crise académica de 1962 e à sua «actuação repressiva em relação aos estudantes [...] e ambígua e contraditória face aos professores e autoridades académicas». Sobre a Academia de Coimbra, de onde procedia Manuel Lopes de Almeida, e a relação desta com o Estado, veja-se a obra de Luís Reis Torgal, A Universidade e o Estado Novo. O Caso de Coimbra. 1926-1961, Coimbra, Minerva, 1999. Lopes de Almeida era lente de História, o que poderá também fazer entender a sua sugestão da temática da história portuguesa para o mural das Letras.

${ }_{13}$ Parecer de Manuel Lopes de Almeida, supracitado.

${ }^{14}$ Veja-se o terceiro verso do poema "D. Affonso Henriques", p. 21 da edição seguinte que neste estudo utilizaremos: Mensagem. Poemas esotéricos, Edição Crítica de José Augusto SEABrA, Madrid, Fundação Eng. A. Almeida, 1993. 
Quem seriam os que, no painel das Letras, através da sua «imagem», «exprimir[i]am» («pelo pensamento ou pela acção») o génio da nação portuguesa ${ }^{15}$ ? A resposta podemos colhê-la na proposta que o pintor, depois de receber do lente das Letras o rol dos nomes a figurar no painel, envia à Comissão de Obras responsável pela construção do "campus" universitário de Coimbra: nas suas palavras, seriam pintados «os vultos de maior realce do génio português» ${ }^{16}$. O professor Lopes de Almeida havia-os arrolado e esse rol serviu de base ao pintor para a proposta que apresentou à Comissão, em Junho de 1949. Dessa lista, composta por quatro nomes da Idade Média, dez da Época Moderna e quatro da História Contemporânea (alguns nomes acrescentados "post" elaboração da lista composta à máquina de escrever) ${ }^{17}$, quase todos foram objecto de representação. Vários desses nomes, e dos que o pintor, de sua lavra, acrescentou, podem ler-se (e até ver-se) também no poema de Fernando Pessoa. Teria o poeta os mesmos objectivos que o professor das Letras e o pintor daquele painel? Provavelmente, pelo menos em última análise, os objectivos tocar-se-iam, mas, não devemos olvidar, muitas das intenções poderão ter sido bastante dissimilares e os resultados corresponderão ao grau de maior génio artístico de Fernando Pessoa (autor de dianteira poética, embora em "Mensagem" esta questão possa ser menos evidente) e às características de um autor bastante académico e de pincel estritamente ortodoxo.

Alistemos, ainda sem grande preocupação de síntese conclusiva, os vultos comuns à obra de Pessoa e à obra de Portela Júnior. $\mathrm{O}$ «Pae» Afonso Henriques aparece no painel com a cota de armas de um guerreio, alusão à sua «inteira força», na expressão pessoana. Outrossim o «plantador de naus», que em "Mensagem" escreve «um seu Cantar de Amigo», figura no fresco das Letras.

${ }^{15}$ Lembremos que a palavra "génio" é de teor religioso. Na Idade Antiga todas as nações, como todos os indivíduos, tinham o seu génio. A título exemplificativo, no painel fronteiro ao de Portela Júnior, da autoria de Joaquim Rebocho e dedicado a fazer "Alegoria da Antiguidade Clássica", junto à figura do imperador Augusto (desenhada através de uma citação da estátua de Augusto da Prima Porta), pintou-se o Génio de Roma, como tivemos oportunidade de identificar no estudo que já citamos: Marco Daniel Duarte, Faculdade de Letras da Universidade de Coimbra. Ícone do Poder..., p. 72, 76 e 84-85.

${ }^{16}$ Carta de Severo Portela Júnior à Comissão de Obras da Cidade Universitária de Coimbra, datada de 1949.06.08; AUC, CAPOCUC, Pasta 275.

${ }^{17} \mathrm{O}$ rol de Lopes de Almeida era composto por: "D. Afonso Henriques, Santo António, D. Dinis, Infante D. Henrique, D. João II, Afonso de Albuquerque, Gil Vicente, Camões, João de Barros, Pedro Nunes, Fr. Heitor Pinto, Padre António Vieira, S. João de Brito, Marquês de Pombal, Alexandre Herculano, Almeida Garrett, Eça de Queirós, J. Leite de Vasconcelos". Vide, como já citámos, o Parecer de Manuel Lopes de Almeida. Os nomes acrescentados manuscritamente foram: D. Afonso Henriques, Afonso de Albuquerque, Eça de Queiroz, José Leite de Vasconcelos. 
Mais que no fresco, pois D. Dinis não figura com atributos ligados à poesia, é na memória descritiva que o autor entrega à Comissão para aprovação (texto que é também um documento de excepção para análise das intencionalidades das representações ${ }^{18}$ ) que encontramos o paralelo claro com o poema de Pessoa, pois o autor justifica a inserção do rei D. Dinis, em primeiro lugar, por ser poeta:

«A seguir a Afonso Henriques mas em plano inferior coroado e envolto em manto real El Rei D. Dinis o poeta e fundador da Universidade a que se destina a nossa decoração. À frente e um pouco abaixo sua esposa a Rainha Santa tão venerada em Coimbra. Faremos por indicar no regaço uma alusão ao milagre do pão e das rosas. Hesitámos quanto à posição a ocupar por estes dois personagens, qual dos dois deveria estar à frente? O Rei ou a Rainha? Por razões de ordem sentimental e estética optamos pelo arranjo apresentando a Rainha Santa à frente» ${ }^{19}$.

Fernando Pessoa não se compadece com «razões de ordem sentimental»; a sacralidade solene da sua estética no poema "Mensagem" não permite, sequer, a figuração de Isabel, rainha santa ${ }^{20}$. Também figurou um rosto feminino adentro dos governantes e notáveis dos dias da medievalidade e dos da aurora da modernidade: escolheu «D. Philippa de Lencastre». A imagem feminina da monarquia medieval portuguesa (portanto, descontando D. Teresa, da monarquia portucalense) é, em Pessoa, Filipa de Lencastre (cronologicamente anunciadora da modernidade que levará à «possessio maris»), mas, em Portela Júnior, «por razões de ordem sentimental» ${ }^{21}$ (como vimos, na expressão do autor da pintura), é Isabel de Aragão.

Nuno Álvares Pereira é celebrado tanto na composição poética como na pintura das Letras, tendo, quer num quer noutro, papel de grande preponderância. Em Pessoa, esta personagem ocupa o plano mais importante do "Brasão" começado a desenhar-se com "Os Campos", formado por "Os Castellos" e “As Quinas" e terminado com "O Timbre”. Naquele "Brasão", Nuno Álvares

${ }^{18}$ A comparação é lícita apenas porque os valores simbólicos inclusos nos dois textos (memória descritiva de Portela Júnior e "Mensagem" de Fernando Pessoa) são, verdadeiramente, coincidentes; repisamos (no conteúdo e não na forma): a coincidência formal e estética seria impossível, pois, neste caso, estamos comparando uma obra literária com um documento de trabalho.

${ }^{19}$ Memória descritiva do painel. AUC, CAPOCUC, pasta 275.

${ }^{20}$ A priori uma incongruência, pois se temos vindo a notar a inclusão do sagrado no poema de Pessoa seria lógico que a Rainha Santa Isabel tivesse sido integrada em "Mensagem"; no entanto, a sacralidade pessoana não é a da devoção popular, mas a da liturgicidade pensadamente depurada e cerebral, afastada da piedade emocional.

${ }^{21}$ Memória descritiva do painel. AUC, CAPOCUC, pasta 275. 
Pereira é, ele só, “A Coroa”. Como mais adiante veremos, também a posição do condestável Nuno Álvares será, no painel das Letras, de suma importância, pelas mesmas razões que Fernando Pessoa viu nesta figura para lhe conferir (não fosse ele "A Coroa") tão alto protagonismo 22 .

Como já foi verificado, «é curioso que, para ilustrar a Coroa - símbolo real por excelência - do brasão português, Pessoa tenha escolhido o Condestável e não um rei, ainda que Nun'Álvares viesse a ser antepassado directo dos reis da quarta dinastia $[. .].\rangle^{23}$. No final deste estudo, será mais fácil percebermos como a escolha de Pessoa, aquilatada com a opção de Portela Júnior (similar à estratégia pessoana), de adensar o sentido da figuração de Nuno Álvares Pereira se enquadra na dimensão doxológica da celebração de Portugal.

Ao figurar as personagens ligadas à epopeia marítima, o pintor, recorrendo, certamente, a finos critérios de selecção, representa o vulto tido como iniciador (o Infante D. Henrique), faz figurar um representante dos descobridores (João Gonçalves Zarco) e desenha um representante da posse da terra descoberta (o Governador da Índia Afonso de Albuquerque). Dois destes cabiam também nos ainda mais sublimados critérios de selecção de Fernando Pessoa e são também alvo de representação em "Mensagem", surgindo colocados - em companhia de uma outra figura não coincidente com o painel das Letras (D. João II) - no mesmo grupo, que Pessoa denomina de "O Timbre"24.

${ }^{22}$ Adrien RoIg, no texto que intitula Mensagem: Heráldica e Poesia, chama a atenção para o facto de, não obstante a coroa ser de suma importância, haver, no esquema heráldico de que Fernando Pessoa se serve, um elemento ainda mais alto: "O Timbre" («todo este edifício do Brasão coroado é ainda dominado pelo Timbre, mais alto, sempre mais alto [...]»), p. 291 de "Mensagem. Poemas esotéricos...". O Timbre é, como disso faremos nota mais adiante, ocupado por três personalidades relacionadas com as Descobertas: "O Infante D. Henrique", "D. João o Segundo" e "Affonso de Albuquerque".

${ }^{23}$ António Apolinário LouREnço (quadros cronológicos, introdução, bibliografia selectiva, fixação de texto e notas), Mensagem, Braga - Coimbra, Angelus Novus, Editora, 1994; veja-se a nota 56 (p. 68) desta edição de "Mensagem".

${ }^{24}$ Portela Júnior dá conta, na sua memória descritiva, da falta de muitas personalidades históricas e, curiosamente, uma das que lhe serve de exemplo é, precisamente, D. João II: «faltam muitas personalidades? Evidentemente [...]. Faltam D. João II, os da Ínclita Geração, Gama, Bernardes, os da Restauração, o épico Mousinho, El Rei D. Carlos e tantos outros? Mas o génio português não se traduz só pela figuração objectiva de todos os seus santos, heróis e homens de pensamento, é mais que tudo a sugestão do seu espírito. Os que ali faltam estão nos túmulos, nas naus, no mar que se adivinha para lá do padrão da conquista, estão enfim presentes na figura simbólica da Pátria» (Memória descritiva, AUC, CAPOCUC, Pasta 275). 
A representação de Portela Júnior, obviamente balizada pelo retrato oficial do Infante nos anos do Estado Novo ${ }^{25}$, é muito concordante com a descrição poética que o autor da "Mensagem" faz daquele a quem apelida, na titulatura do poema, de "A Cabeça do Grypho". Os cinco versos de Pessoa são verdadeiramente uma descrição iconográfica da efígie através da alusão à representação icónica tradicional da figura do "imperator" (com o "mundus" na mão); as palavras são do poeta:

«o único imperador que tem, deveras,

O globo mundo em sua mão» ${ }^{26}$.

A ajudar a visualização da imagem de D. Henrique, o vocábulo "manto" (que Pessoa caracteriza de escuro - «manto de noite e solidão») e a referência, no primeiro verso, ao seu trono fazem completar o ícone sobejamente conhecido que a memória colectiva nacional detém do Infante e que, reforçamos, em Pessoa é eminentemente visual ${ }^{27}$. De relevância para este estudo é o facto de a valorização da figura do Infante pintada por Portela Júnior ser, com efeito, similar à da narração de Fernando Pessoa, talvez não porque ali tenha ido buscar inspiração (embora não fosse inverosímil), mas, fundamentalmente, porque para a representação (literária ou pictórica) desta personagem ambos os autores se basearam na iconografia tradicional do "Navegador" 28 . Na maqueta do fresco, ainda mais que na obra, o Infante «tem aos pés o mar novo e as mortas eras», pois coloca o pé esquerdo sobre uma esfera armilar, símbolo de

${ }^{25}$ Sobre o retrato oficial de D. Henrique, veja-se Ernesto SoARES, Henrique de Campos Ferreira Lima, Dicionário de Iconografia Portuguesa (retratos de portugueses e de estrangeiros em relações com Portugal), Lisboa, Instituto para a Alta Cultura, 1960, II suplemento, V volume, p. 173-277. Deste autor é o estudo Iconografia do Infante D. Henrique, Lisboa, Tipografia da Gráfica Santelmo, 1959. Veja-se, ainda, Pedro Dias (comissário científico), "O Rosto do Infante", catálogo da exposição com o mesmo nome, Tomar, Viseu, Comissão Nacional para as Comemorações dos Descobrimentos Portugueses, 1994; nesta obra, veja-se, em particular, Nuno Rosmaninho, Os Artistas do Estado Novo e a Visão do Infante, p. 132-179. Atente-se, também, na iconografia reproduzida na publicação periódica Oceanos. $O$ ano do Infante, Comissão Nacional para as Comemorações dos Descobrimentos Portugueses, 1994, n. ${ }^{\circ}$ 17, Março de 1994, e no trabalho de Pedro Dias, Criação e recriação da imagem do Infante D. Henrique na época moderna, em "Actas do XII Encontro de Professores de História da Zona Centro", Coimbra, 1994, p. 149-169.

${ }^{26}$ Últimos versos do pequeno poema "O Infante D. Henrique".

${ }^{27}$ Mais tarde, no rosário de "Mensagem”, o autor do poema a este Infante voltará e, nesse retomar, não se tratará já de uma iconografia visual, mas de uma ideação mais abstracizante a partir da imagem de Henrique navegador: veja-se no poema pessoano "O Infante", a primeira peça de "Mar Portuguez" (segunda parte de "Mensagem").

${ }^{28}$ Veja-se o dicionário de Ernesto SoAREs que já citámos. 
todo o planeta descoberto e por descobrir. No entanto, embora não o saibamos concretamente, alguém deve ter intervindo no momento de ideação da obra e o Infante da pintura, não obstante ostentar um escuro traje de «noite» (coincidente com a descrição de Pessoa), coloca o pé sobre um pequeno degrau que the permite exibir a mesma posição corporal que, por razão pragmática, o pintor não modificou. Como veremos, embora a obra pictórica final se afaste, neste ponto, da iconografia da pena de Pessoa (ficando, todavia, ainda muito próxima), a maqueta tinha sido gizada com valores ainda muito mais aproximados. No painel pintado, a esfera armilar - com os símbolos astrológicos do Zodíaco - ficou mais adiante, ainda que na área de influência da figura do chapeirão. No entanto, se com esta descrição que fazemos pudéssemos ter a sensação de as obras que analisamos se tornarem dissemelhantes, encontramos similitudes que as aproximam: à expressão «globo mundo em sua mão» corresponde, não um globo, mas um planisfério portulano que o Infante do painel das Letras segura em sua mão, mostrando, a quem passar o vestíbulo da Faculdade, a mesma ideia de imperial dominação sobre o mundo ${ }^{29}$.

Afonso de Albuquerque, «A Outra Asa do Grypho», está no mesmo grupo do Infante. Tanto o pintor como o poeta o visualizaram «de pé» e, não tendo neste ponto seguranças científicas, talvez os «olhos cansados» da expressão pessoana sejam também visíveis no fresco da Faculdade de Letras ${ }^{30}$.

Para descrever a «possessio maris» portuguesa, Fernando Pessoa engendra um vasto cenário, munindo-se de personagens históricas ("O Infante", novamente), mitológicas ou lendárias ("O Mostrengo"), de locais ("As Ilhas Afortunadas"), de objectos (um "Padrão", um "Epitaphio [...]”, "A Ultima Nau")... Para a alegoria criada por Portela Júnior para as Letras de Coimbra também alguns destes foram chamados a compor o cenário da nação e assim se fazerem ícone dos séculos das descobertas que, na época estadonovista, com tanto enlevo se evocavam: assim aparecem, nesta esteira, um padrão e uma nau. Ao escrever "Padrão", Fernando Pessoa descreve o conhecido monumento de

${ }^{29}$ A representação de D. Henrique na tela "Alegoria da Escola de Sagres”, do mesmo Severo Portela Júnior, no Museu da Marinha (em Lisboa), é decalcada no painel das Letras de Coimbra e, como neste, D. Henrique aporta um mapa-mundo. Muito curiosa é a posição do figurado que está, precisamente, com um pé sobre um degrau, exactamente como na composição pictórica do vestíbulo da Faculdade de Letras.

${ }^{30}$ É curioso que a representação se faz a partir da iconografia tradicional do representante do rei na Índia, mesmo depois de se conhecer o restauro do quadro que deu origem a essa tradição iconográfica e das consequências desse restauro: a revelação de uma nova efígie de Afonso de Albuquerque bem diversa da seguida por Severo Portela Júnior. No painel das Letras representa-se o governador da Índia de longa barba torça, rematada com um aro. Sobre a questão iconográfica desta figura histórica, veja-se Ernesto SoAREs, Dicionário de Iconografia Portuguesa ..., p. 67 e 68. 
pedra constituído por coluna com remate cruciforme, dizendo que este marco tem por missão «assinalar» e «ensinar» (são verbos do poema) ao mundo o facto de os portugueses terem cumprido a sua missão; para o sujeito poético e, seguramente, para o poeta, se algo faltar à consumação deste desígnio, será já da responsabilidade do sobre-humano ${ }^{31}$. No poema "Mensagem", o padrão aparece exactamente como um sinal. Há, inclusivamente, uma descrição (ainda que não exaustiva, bastante significativa) dos elementos fundamentais que formavam o padrão português: as «Quinas» e a «Cruz ao alto»" ${ }^{32}$. Não se representando as quinas, mas antes a sugestão de uma legenda, o padrão pintado nas Letras também ostenta, ao alto, a Cruz. O poema "Padrão" faz ainda sugestão, e de forma bastante erudita, de outro sinal também perenizado numa placa lítica que Portela Júnior representa: trata-se da referência - sem dizer o seu nome, mas o do seu autor moral - à Pedra de Ielala que os homens de Diogo Cão gravaram nas margens do rio Zaire. Também Portela Júnior insere esta imagem na sua alegoria ${ }^{33}$.

Não sabemos se as embarcações figuradas no painel das Letras serão a «última nau» que Pessoa glosa em nostálgica toada. Talvez a descrição que o pintor Portela Júnior fazia das «embarcações de 500 ambas com velame enrolado» ${ }^{34}$ se adequasse mais ao poema de Pessoa, na medida em que as velas da pintura aparecem já desdobradas e prontas para uma partida, ao passo que as da narração pessoana estarão, depois de terem erguido «como um nome, alto o pendão / do Império», aportadas, como diz Pessoa, numa «ilha indescoberta» ${ }^{35}$.

Algumas das figuras insertas em "Mensagem" não aparecem no painel de Severo Portela Júnior, mas noutros locais de figuração do edifício da Faculdade de Letras, o que revela, uma vez mais, a oportunidade da representação e faz ver como, quer os espaços que compõem o longo poema de Pessoa, quer os diferentes espaços de figuração do edifício das Letras da Universidade de Coimbra, se munem da iconografia nacional para, eruditamente, celebrarem

${ }^{31}$ Seguimos de perto o que se diz na segunda estrofe de "O Padrão": «Este padrão signala ao vento e aos céus/ Que, da obra ousada, é minha a parte feita:/ O por-fazer é só com Deus»».

${ }^{32}$ Vejam-se, do poema "Padrão", as estrofes terceira e quarta, respectivamente.

${ }^{33} \mathrm{O}$ desenho das inscrições de Ielala situa-se, sem grande empenho simbólico, mas com algum interesse formal, na sombra do escudo nacional, no patamar abaixo do local de representação de São João de Brito.

${ }^{34}$ Severo Portela Júnior, Memória descritiva do painel das Letras, AUC, CAPOCUC, pasta 275 .

${ }^{35}$ Expressão de Fernando Pessoa no poema “A Ultima Nau”. 
valores comuns ${ }^{36}$. Das figurações que integram o poema de Pessoa, podemos ver, nos espaços da Faculdade de Letras, por exemplo, a representação de Ulisses, quer nos portões (onde se dedicam doze relevos à "Ilíada" e à "Odisseia"), quer no fresco fronteiro ao que aqui analisamos de forma mais pormenorizada, pintado pelas mesmas datas, da autoria de Joaquim Rebocho e que é dedicado à Antiguidade Clássica. Tal como nos relevos de bronze se narram as venturas do herói homérico, também no fresco se faz evocação de Ulisses - «o mytho é o nada que é tudo» - que Pessoa relaciona com as raízes da cidade de Lisboa. Também nos relevos de bronze se podem apreciar, na porta dedicada a Camões (na sua criação lírica e épica), as "Ilhas Afortunadas", obviamente, tomando como fonte para a criação escultórica o trecho correspondente de "Os Lusíadas"37.

Ainda mais do que estas encenações que aqui apontamos exteriores ao conjunto das figurações do painel que constitui o "corpus" em equação para a comparação com "Mensagem", é de especial importância, neste estudo, um relevo do portão central (de bronze, como os restantes outros), da direcção artística de Salvador Barata Feyo, mas da elaboração de um dos seus alunos ${ }^{38}$, dedicado a Fernando Pessoa. Estamos, neste ponto, a perceber uma outra questão relacionada não apenas com o facto de na Faculdade de Letras se celebrarem os mesmos episódios históricos que são celebrados em "Mensagem", mas, facto muito relevante, de um desses motivos de celebração ser, precisamente, o autor de "Mensagem", Fernando Pessoa. Ainda mais digno de nota neste estudo é a verificação de que, de toda a vastíssima obra de Fernando Pessoa, foi exactamente o seu poema "Mensagem" o escolhido para perenizar homenagem ao poeta ${ }^{39}$. Com efeito, é através do poema "Mostrengo" que se representa

${ }^{36}$ Os locais onde se faz figuração na Faculdade de Letras da Universidade de Coimbra são os que estudámos no livro a que já nos referimos, Faculdade de Letras da Universidade de Coimbra. Ícone do Poder ...: as quatro estátuas do átrio exterior, os trinta relevos de bronze das cinco portas do edifício, os dois murais do vestíbulo de honra, os quatro relevos das entradas do prédio e a tapeçaria da sala do Conselho.

37 Ainda assim, poderemos ver coincidência entre a interpretação e exploração pessoana da temática de "As Ilhas Afortunadas" e o relevo da Faculdade de Letras da Universidade de Coimbra que, não obstante ser retrato do Poeta do Renascimento, reproduz a ambiência do local indefinível (inexistente, quiçá: «terras sem ter lugar») que o texto de "Mensagem" salienta. Com efeito, o relevo de bronze coloca os dois figurados numa porção de terra com contornos pouco definidos.

${ }^{38}$ Veja-se sobre a autoria dos relevos o que dizemos em Faculdade de Letras da Universidade de Coimbra. Ícone do Poder..., p. 42-43.

${ }^{39}$ Os portões das Letras estão dedicados a Gil Vicente (seis relevos representativos de autos), a Homero (doze relevos figurativos de "Ilíada" e "Odisseia"), a Camões (seis relevos evocativos da sua lírica e da sua épica) e, o do centro, através dos seis relevos esculpidos, a seis poetas 
Fernando Pessoa e, porque o rasgo escultórico se prende com bastante fidelidade à fonte literária do qual o relevo se faz representação, a comparação merece ser feita, prescindindo de análise:

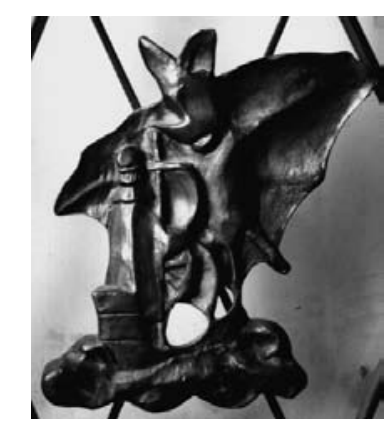

Relevo de bronze da porta central da

Faculdade de Letras representando

Fernando Pessoa através

do poema "O Mostrengo".

(fotografia de Marco Daniel Duarte)
O mostrengo que está no fim do mar

Na noite de breu ergueu-se a voar;

À roda da nau voou três vezes,

Voou três vezes a chiar,

E disse: "Quem é que ousou entrar

Nas minhas cavernas que não desvendo, Meus tectos negros do fim do mundo?"

E o homem do leme disse, tremendo:

"El-Rei D. João Segundo!"

"De quem são as velas onde me roço? De quem as quilhas que vejo e ouço?" Disse o mostrengo, e rodou três vezes, Três vezes rodou imundo e grosso, "Quem vem poder o que só eu posso, que moro onde nunca ninguém me visse e escorro os medos do mar sem fundo?" e o homem do leme tremeu, e disse, "El-Rei D. João Segundo!"40

Olhadas que estão as figurações comuns aos vários espaços de "Mensagem" e aos diferentes espaços (inclusivamente outros, diversos do painel de Portela Júnior) da Faculdade de Letras, voltemos ao fresco da "Glorificação do Génio Português", pois ele é, com efeito, o que, no seu teor (menos na forma artística), mais se relaciona com o mundo de conteúdos conjugado por Fernando Pessoa.

Encostado à ilharga esquerda para quem observa, alcandorada num púlpito, aparece a figura do jesuíta António Vieira, com o braço rasgando o astro em viva atitude de prédica de acção. A figura representa Vieira no desempenho do seu múnus apostólico de pregador. O «Imperador da língua portuguesa»

portugueses contemporâneos: Cesário Verde, Florbela Espanca, Eugénio de Castro, Antero de Quental, Fernando Pessoa e António Nobre.

${ }^{40}$ Apenas transcrevemos a primeira e segunda estrofes do poema "O Mostrengo"; na transcrição destacámos as partes que melhor se notam na interpretação escultórica. 
é apresentado em "Mensagem" através de uma elaboração poética que the enfatiza, nas doze linhas que a constituem, o seu carácter de sábio. Como tal, a sua posição está acima da do comum dos mortais e, num requinte sumamente sabedor por parte do poeta, é descrito como um céu; um céu estrelado no meio de tantos outros céus de estrelas que constituem o firmamento português (ou, como temos feito notar, o panteão português $)^{41}$. No painel de Portela Júnior, este céu surge também no meio de tantos outros céus e o seu "modus representandi", quer em "Mensagem", quer em "Glorificação do Génio Português", permitirá lembrar a comparação (nítida em Pessoa) aos sábios dos quais se faz elogio no livro sagrado do profeta Daniel ao dizer-se que «resplandecerão como a luminosidade do firmamento» ${ }^{42}$. Como escreveu o profeta das visões do tempo de Nabucodonosor, «os que tiverem levado muitos aos caminhos da justiça brilharão como estrelas com um esplendor eterno» ${ }^{43}$. Não sabemos se Severo Portela Júnior terá figurado António Vieira lembrando-se, como Pessoa, que na mente-meditação do pregador «surge, prenúncio claro do luar, El-Rei D. Sebastião» ${ }^{44}$, mas estamos certos de que foi pelos seus dotes de sábio que tanto um como o outro o incluíram nas respectivas composições.

O observador atento a ambas as figurações, o interpretador mais ousado, poderá fazer corresponder, inclusivamente, a sapiente descrição pessoana da sapiência de António Vieira ao púlpito de Santa Cruz que, em sabedora citação (embora em verosimilhança pouco possível), Portela Júnior coloca como suporte material da pregação. Iconograficamente, a inclusão do púlpito no painel justifica-se do mesmo modo que se justifica a presença de figurações de outras obras de arte como são os painéis de São Vicente de Fora e a custódia de

${ }^{41}$ Outra figura que em "Mensagem" também se encontra representada debaixo deste signo da sabedoria é o Infante: «entre o brilho das estrelas»; primeiro verso do poema "A Cabeça do Grypho/ O Infante D. Henrique".

42 Profecia de Daniel 12, 3.

${ }^{43}$ Idem. Foi também assim que entendemos a figuração que, no caso que ora trazemos para comparação, Almada Negreiros fez do navegador D. Henrique e do matemático Pedro Nunes no painel sobre "A Matemática ao serviço da epopeia nacional", painel que pintou para o vestíbulo do Departamento de Matemática da Faculdade de Ciências da Universidade de Coimbra, sua última obra, que tivemos oportunidade de estudar em Matemática Pictórica: a Matemática (dos Caldeus, dos Egípcios, de Pedro Nunes, de Einstein e de tantos outros) pintada por Almada Negreiros, em Actas das "Jornadas do Mar 2002 - Colóquio Pedro Nunes. Novos Saberes na Rota do Futuro", Almada - Alfeite, Escola Naval, [2003], p. 83-97; a questão relacionada com a figuração das personagens num universo cintilante encontra-se na p. 70.

${ }^{44}$ Poema dedicado ao pregador "Antonio Vieira", o "Segundo" de "Os Avisos" de "Mensagem". 
Belém ${ }^{45}$, mas iconologicamente poderíamos entrever pontos de contacto entre a figuração de um dos mais sábios vultos da nação e a representação de um dos púlpitos de onde se pregaram sermões de erudição ou não fosse o mosteiro agostinho de Santa Cruz de Coimbra uma das casas onde mais se cultivava o saber em Portugal pelos anos das Idades Média e Moderna ${ }^{46}$. Do mesmo modo que Vieira é mais uma das personagens-etapas que, em "Mensagem", ajuda a construir o edifício solenemente laudatório de Portugal, também no painel de pintura o jesuíta é colocado, através do seu olhar e através do seu gesto rasgado, teatralmente típico do meneio parenético, como mais uma peça que, com outras, ajuda a enfatizar a ideação que se quer apresentar e, deste modo, o vemos a apontar o céu e a olhar ${ }^{47}$ a espada que remata, do ponto de vista ideográfico, eficazmente, o quadro alegórico e que, nessa eficácia, se deverá ler como uma verdadeira cruz. Falamos, como de seguida desenvolveremos, da espada-cruz de Nuno Álvares Pereira.

Obviamente que não haverá tão-só coincidências entre as obras que analisamos e muitas dissemelhanças existirão. Apontámo-las, desde logo, nas primeiras linhas deste estudo, fazendo nota, de uma forma mais relevada, das várias questões que se relacionam com as diferenças estéticas entre "Mensagem", de Fernando Pessoa, e "Glorificação do Génio Português", de Severo Portela Júnior. Se o primeiro se inscreve nas obras de primeira água da criação estética, o segundo é uma marca do seu tempo, documento,

${ }^{45} \mathrm{Na}$ memória descritiva o autor escreve: «não esquecemos as artes [...]»; «os nossos lavrantes da pedra, do ferro, e do oiro estão também presentes nas suas obras maiores; os túmulos de Alcobaça[,] o púlpito de Santa Cruz[,] a Sé Velha de Coimbra[,] a grade da Sé de Lisboa[,] a custódia de Belém». AUC, CAPOCUC, Pasta 275.

${ }^{46}$ Não obstante a representação inclusa no fresco não oferecer dúvidas em tratar-se de uma citação do púlpito renascentista de 1521, da mão de Nicolau Chanterenne, e de, inclusivamente, o autor, na memória descritiva (veja-se nota supra) a ele fazer alusão, a reprodução do esboço que se conserva no Arquivo da Universidade de Coimbra não deixa perceber que se trate daquele púlpito em concreto. Na verdade, ao passo que as restantes obras declaradas por escrito se vêem no esboço (a grade da sé de Lisboa, a custódia de Belém...), o púlpito ali figurado não é reconhecível nem sequer se aparenta na sua tipologia com o de Santa Cruz. Cabe aqui dizer que também a personagem que, no esboço, é desenhada sobre o púlpito não se relaciona com a iconografia de António Vieira. Poderia tratar-se de um qualquer pregador (talvez dominicano, pelo desenho do hábito...): por exemplo, não seria descabida a sua inserção, poderia tratar-se do jerónimo Frei Heitor Pinto.

${ }^{47}$ Como tantos outros, mas não quaisquer outros: D. Afonso Henriques, a Rainha Santa Isabel, São João de Brito e Nuno Álvares Pereira. 
de valor artístico, sem dúvida, que servirá, sobremodo, para o conhecimento do passado, mas que não influenciará as correntes pictóricas nem será, como o poema pessoano, objecto de repetidas análises e estudos nos mais variados contextos do ensino e da cultura. Outra característica que separa as obras em análise neste estudo, como também notámos desde o início do exame, será a que se relaciona com os tempos da criação, as datas da elaboração que, com efeito, as afastam em mais de década e meia.

O exercício de comparação que aqui estabelecemos entre o poema de Pessoa e a pintura de Portela Júnior poderia operar-se com outras obras como, por exemplo, com a de Ramiro Guedes de Campos, saída em letra de forma em 1937, três anos depois de "Mensagem", levando o título "Portugal"48, precisamente, uma das hipóteses de título que Pessoa havia equacionado para a sua obra ${ }^{49}$. O facto de o poema de Ramiro Guedes de Campos ser premiado, no ano de 1937, com o mesmo Prémio Antero de Quental do Secretariado de Propaganda Nacional com que três anos antes havia sido premiado "Mensagem" (embora este, como é conhecido, numa categoria extraordinária e menos valorada, relativamente ao concurso) torna, desde logo, legítima a comparação. Colocando de parte a questão estética - embora conscientemente, propomos, uma vez mais, que corramos esse risco (é indubitável que estejamos a mutilar a análise, pois a estética será sempre parte intrínseca na obra de criação artística) -, o poema de Guedes de Campos surge comparável, quer à composição de Pessoa, quer à elaboração pictural de Portela Júnior. A razão será simples de encontrar: Ramiro Guedes de Campos é mais um autor a recorrer a personagens e cenários da nação portuguesa para, utilizando-os como ícones, elaborar um poema laudatório da nação. Assim se vêem personalidades comuns como, a título exemplificativo, D. Henrique, Afonso de Albuquerque, António Vieira ${ }^{50}$. Nalguns aspectos este poema aparentar-se-á mais com a pintura de Portela Júnior, pois com esta tem em comum a característica de não pertencer à galeria das obras de estética de primeira água e de, declaradamente, fazer louvor a alguns ícones de carácter político omitidos por Pessoa e que aparecem em Portela Júnior: um exemplo do que falamos é a figuração, em "Portugal. Poemas" e em "Glorificação do

${ }^{48}$ Ramiro Guedes de CAmpos, Portugal. Poemas, Lisboa, Editorial Império, 1937.

${ }^{49}$ Como é sumamente conhecido, Fernando Pessoa ponderou a hipótese de intitular o conjunto de poemas de "Mensagem" com a palavra "Portugal". A edição de "Mensagem" que temos utilizado nas referências ao poema reproduz, nas p. 408 e 409, dois esbocetos onde se vê a hesitação de Fernando Pessoa entre o título "Portugal" e o título "Mensagem".

${ }^{50}$ Apontamos apenas exemplos comuns às três obras em apreço: a de Campos, a de Pessoa e a de Portela. Há elementos comuns à primeira e à segunda, bem como à primeira e à terceira que, por uma questão de economia de espaço, não vamos sequer elencar. 
Génio Português", do célebre ministro de D. José, o Marquês de Pombal. Neste trilho de análise que ora operamos, assinalemos que outro ponto comum apenas a estas duas obras é a referência ao Estado Novo como época de salvação. No poema de Ramiro Guedes de Campos, na parte dedicada ao século XX, diz-se sobre uma visão de um homem que facilmente nos fará pensar em António de Oliveira Salazar como o novo D. Sebastião do século XX:

«E um Homem vejo enfim, virtuoso e grande, na multidão surgir de homens pequenos, Braço que Deus mandou para que mande Com gestos luminosos e serenos;

A lei constante e igual por gláudio brande Que a todos mais exalte e a nenhum menos; Eis sobe, como deve, a ilustre mando Contra vontade sua e não rogando» ${ }^{51}$.

Ainda adentro da questão da referência ao regime de Salazar, poderemos encontrar paralelo com o painel das Letras, não tanto no que ficou figurado, mas mais no que o autor escreveu na proposta datada de Junho de 1949, onde, depois de enunciar as variadas figurações que pintaria (citadas da exposição de Lopes de Almeida a que demoradamente fizemos referência), afirma que procuraria «introduzir na composição um elemento que sugirá ["sic", provavelmente em lugar de sugerirá] o esforço nacionalista do Regime» ${ }^{52}$.

${ }^{51}$ Estrofe CIII de "Portugal. Poemas" que o autor intitula "Aparição", p. 164. Luís Reis Torgal, no estudo apresentado com o título Literatura Oficial no Estado Novo. Os Prémios Literários do SPN/SNI, em "Revista de História das Ideias", Coimbra, Instituto de História e Teoria das Ideias, Faculdade de Letras da Universidade de Coimbra, 1999, vol. 20, p. 401-420, ao analisar este poema de Guedes de Campos, escolhe a estrofe que transcrevemos, precisamente, por elucidativa sobre o apego daquela epopeia poética ao Estado Novo. O historiador deste período da história portuguesa, ao analisar a estrofe, escreve o seguinte: «e, saindo desta sombra, haveria a "Aparição" de um Chefe - Salazar, sem dúvida - que através da "palavra" [...] traria a paz e o renascimento do Império» (p. 416 do artigo de Luís Reis ToRGAL).

52 Proposta de decoração apresentada pelo pintor em 1949.06.08 à Comissão de Obras; AUC, CAPOCUC, Pasta 275, Pintura a fresco das paredes do átrio da Faculdade de Letras. Na obra final não se denota de uma forma especial esta intenção. No estudo que fizemos sobre as figurações icónicas na Faculdade de Letras da Universidade de Coimbra, colocamos a hipótese desta alusão ao «esforço nacionalista do Regime» poder ter sido materializada numa enevoada cena bélica que aparece na zona cimeira do fresco, mas, como dissemos, é apenas uma conjectura. Veja-se o que escrevemos em Faculdade de Letras da Universidade de Coimbra. Ícone do Poder..., entre as p. 108 e 112 . 
A coincidência dos símbolos nas três obras que, neste breve momento, equacionamos é, para o iconógrafo, facilmente explicável, embora este não se deva arrogar na compreensão em plenitude das realidades figuradas: os autores, recorrendo a uma mesma colecção iconográfica, tendo objectivos similares no que respeita à exaltação nacional, munem-se de imagens (ícones) colhidas no mesmo "thesaurus" iconográfico, independentemente de com os mesmos materiais efectuarem escolhas dissemelhantes assentes em critérios correspondentes à específica mensagem que pretendem, com a sua obra, transmitir.

\section{un}

Se não temos dúvidas de que há, em "Mensagem”, uma intenção de envolver numa aura sacralizante as personagens escolhidas, pretendemos também evidenciar que essa intenção se encontra no fresco da Faculdade de Letras da Universidade de Coimbra. Para trás ficou já demonstrado que era esse o desígnio dos que planearam aquele fresco; a própria expressão chamada a dar título ao painel assim o denuncia: "Glorificação do Génio Português".

Com efeito, se já nas palavras de Manuel Lopes de Almeida, professor da Faculdade de Letras, apoiadas por Amorim Girão, director daquela Faculdade, se percebia esta aura de religiosidade, é na obra propriamente dita que essa característica se pode perceber com maior justeza. Ao medirmos o quadro segundo as linhas da sua formulação geométrica, facilmente nos apercebemos de que as personagens (muitas, como o próprio autor dirá: «muitos varões assinalados»; 《esteticamente gente de mais» ${ }^{53}$ ) foram dispostas de modo a poderem fazer alegoria. Assim, nem todos têm os mesmos tamanhos; por exemplo, a figura central, à volta da qual gravitam todas as outras, ficou desenhada em escala maior que as restantes: é a figuração da Pátria, uma mulher madura, coroada de louros e sentada junto a um forte escudo nacional, tão possante nas suas linhas como a própria personificação da Pátria resulta possante, como já se depreendia da descrição do pintor relativa a esta «figura simbólica da Pátria»:

53 «Dada a escassez de espaço a maior dificuldade consistia em instalar à vontade tantos varões assinalados com os seus respectivos atributos»; esta é a frase que, no início da memória descritiva, manifesta a preocupação do autor relativamente ao avultado número de personagens a representar. No final do mesmo documento, Portela Júnior voltará a expressar esta preocupação nos seguintes termos: «a maior dificuldade consistiu em harmonizar estes dois complexos: esteticamente gente de mais, historicamente gente de menos» (Memória descritiva, AUC, CAPOCUC, Pasta 275). 
«sob a forma clássica de mulher sustendo e amparando-se ao escudo nacional revestida de roupagens ligeiras e certo aspecto marcial. Como se trata de um símbolo demos-lhe proporções maiores $[\ldots]\rangle^{54}$.

Se traçarmos as diagonais e as medianas do campo pictórico, estas linhas unem-se no ponto geométrico ocupado pela mulher representadora da Pátria, ponto fundamental da composição. Para além da métrica que ocupa no campo pictórico, ela distingue-se de todos os outros figurados por não ser uma personalidade concreta (que viveu num tempo e num espaço históricos), mas antes uma alegoria. Percorramos uma dessas linhas da composição do painel, a mediana vertical, e percebamos que ela se inicia no ponto mais em baixo para terminar na espada que Nuno Álvares Pereira segura, no cimo da composição. De todos os figurados por Portela Júnior, Nuno Álvares mereceu ao autor o lugar mais cimeiro da composição, o que demonstra a sua importância para a doutrinação que se queria operar. Adentro da catequização político-ideológica estadonovista, Nuno Álvares Pereira é figura de avultado preito cultual por variadas razões, entre as quais a de ser um herói histórico ligado à independência da nacionalidade, assim como a um dos fundamentais pilares da nação: a religião; D. Nuno Álvares Pereira era membro da Igreja Católica enquanto religioso (embora como irmão leigo) da Ordem do Carmelo e, desde o princípio do século XX (em contexto da Primeira República), declarado Beato, isto é, digno de ascender aos altares e de ser cultuado pelos fiéis. Por isso, a espada que sustenta não é simplesmente a espada de um guerreiro, mas uma espada feita cruz, erguida no mais alto patamar do painel e constituindo-se "terminus" das linhas formais subjacentes à composição plástica.

Acalmemos estas análises e quietemo-nos na comparação directa entre a composição pessoana dedicada a Nuno Álvares Pereira e a figuração desta personalidade pelo pincel de Portela Júnior. Vejamos como um e outro exaltam não só o Beato Nuno de Santa Maria, mas, sobremaneira, a sua espada:

${ }^{54}$ Memória descritiva, AUC, CAPOCUC, Pasta 275. O aspecto marcial não foi grandemente transposto para o painel. 
Nun'Alvares Pereira

Que aureola te cerca?

É a espada que, volteando,

Faz que o ar alto perca

Seu azul negro e brando.

Mas que espada é que, erguida,

Faz esse halo no céu?

É Excalibur, a ungida,

Que o Rei Artur te deu.

Sperança consummada,

S. Portugal em ser,

Ergue a luz da tua espada

Para a estrada se ver!

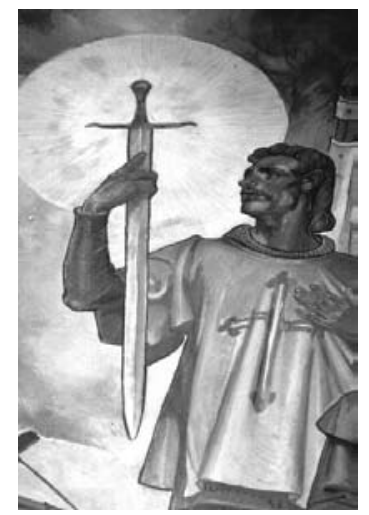

Nuno Álvares Pereira segundo o pintor

Severo Portela Júnior no fresco da

Faculdade de Letras da

Universidade de Coimbra

(fotografia de Marco Daniel Duarte).

Ao compararmos as duas peças não temos dúvidas de que, quer na composição escrita, quer na composição plástica, o enaltecimento maior é posto na espada do santo tornada cruz e, por isso, digna de louvor. A auréola que cerca o santo de Pessoa é a que dimana da espada, tal como se vê na figuração de Portela Júnior. O pintor, contudo, embora tenha figurado desta forma o Beato Nuno, tinha intenção de conferir maior protagonismo à figura do santo do que lhe veio a conferir na obra final. Não porque ignorasse as leis da representação iconográfica, pois disso faz nota na memória descritiva, mas, por um impulso de devoção e de nacionalismo, porque representa, no esboceto, Nuno Álvares com a cabeça cercada por uma auréola. A incongruência iconográfica não passaria no crivo da comissão dos professores da Universidade de Coimbra, pois somente os santos (e não os beatos) poderiam levar a cabeça cercada por um halo. Como já referenciámos, o pintor sabia-o, apesar de tentar um argumento que, contudo, não convencerá os decisores e censores iconográficos:

«certo é que Frei Nuno de Santa Maria não está ainda canonizado mas é natural que esta antecipação não tenha inconveniente dado que a sua canonização está para breve» ${ }^{55}$.

${ }^{55}$ Memória descritiva; AUC, CAPOCUC, Pasta 275. 
O decorrer da história portuguesa demonstrou que a profecia de Portela Júnior, a realizar-se, só seria cumprida a longo prazo, pois, com efeito, não esteve «para breve» a canonização de Nuno Álvares Pereira. O processo de canonização foi reaberto apenas em 13 de Julho de 2003, portanto, cinquenta e quatro anos depois das palavras do pintor. $\mathrm{O}$ resultado final da pintura, depois do crivo da ortodoxia iconográfica, aproxima-se da iconografia traçada por Fernando Pessoa, onde, com efeito, é da espada feita cruz (a mesma «Excalibur» doada pelo «Rei Artur») que provém o «halo no céu» ${ }^{56}$.

Para além de à cruz-espada irem convergir as linhas que formam as arestas do triângulo que subjaz à disposição das figuras do painel das Letras, ela faz-se coincidência da mediana vertical do campo pictórico, reforçando o sentido simbólico desta mesma linha central da alegoria. Verifiquemos, ainda, como o traçado da referida mediana se encontra com duas outras rectas que se estabelecem através da silhueta interna dos diferentes figurados em cada uma das ilhargas e como esse ponto, pensadamente ocupado pela figuração da custódia de Belém, se constitui em mais uma das provas da intencionalidade de figuração do sacro. Sobre um patamar paralelipipédico desenhou-se a jóia da ourivesaria nacional de mil e quinhentos. Será apenas a citação de uma obra artística? Pensamos que não, pois o pilar onde ela assenta tem inscritas as letras que Pessoa tinha pensado em primeiro lugar para o seu poema "Mensagem": "Portugal" Os oito caracteres que formam a palavra "PO-R-TV-GAL", grafados não de um qualquer modo, mas segundo a maneira de assinar os documentos escritos na primeira chancelaria da nação, fazem legenda de toda aquela encenação, tal como a expressão "Portugal", depois substituída por "Mensagem", fazia título de toda a encenação arquitectada por Fernando Pessoa. Se alguma hesitação nos pudesse restar por apenas concluirmos sobre o que foi pintado, a memória descritiva com que o autor fundamentou a sua proposta de ideação e que apresentou, em Novembro de 1949, à Comissão de Obras da Cidade Universitária dissipava-a:

${ }^{56}$ As expressões que Fernando Pessoa utiliza para descrever Nuno Álvares Pereira e a sua espada, para além de se coadunarem com a figuração desenhada no painel da Faculdade de Letras, são as mesmas que o pintor utiliza na memória descritiva preparativa deste painel: «nas mãos do Beato Nuno a sua espada confunde-se com a cruz que envolvida num halo luminoso ele levanta no céu». Por aqui vemos como a reflexão de um e de outro criador foi idêntica e, inclusivamente, como o próprio poema de Pessoa possa ter influenciado Portela Júnior.

57 Vejam-se as já citadas p. 408 e 409 de Mensagem. Poemas esotéricos..., onde se reproduzem as páginas que registaram as mudanças operadas pelo punho de Pessoa em relação ao título da obra. 
«se a parte superior do eixo longitudinal da composição é ocupada pelo símbolo da cruz para nos sugerir que o Génio Português é essencialmente cristão quisemos completar essa ideia e na parte inferior desse eixo figuramos a pedra d'ara do altar da Pátria inscrevendo-lhe a signa de Afonso Henriques entremeada da cruz latina PO-R-TV-GAL. Sobre esse altar colocamos a Custódia de Belém» ${ }^{58}$.

Deste modo, não temos dúvidas de que todos aqueles símbolos que se convocaram para aludir ao génio português foram urdidos com sentido sacral e pontenciados em ordem a fazerem do painel um verdadeiro hagiológio, retábulo à nação, onde se colocaram, em cada nicho, os respectivos santos («exempla») e onde não falta o altar que sustenta a custódia, na mesma linha vertical que conduz ao ápice da máquina retabular com remate em forma de cruz.

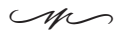

O confronto das obras analisadas pode gerar inferências mais amplas se equacionado no contexto de uma reflexão acerca da epistemologia artística. As palavras de Pessoa sobre os símbolos podem levar-nos à percepção de como a sua, quiçá, «intuição sintética» (para utilizarmos uma expressão de um dos maiores estudiosos da arte simbólica, Erwin Panofsky) se aproxima dos escritos que constroem o saber iconográfico. Lembremos a sua declaração sobre a maneira de interpretar os símbolos, através de cinco patamares:

«O entendimento dos símbolos e dos rituais (simbólicos) exige do intérprete que possua cinco qualidades ou condições, sem as quais os símbolos serão para ele mortos, e ele morto para eles $\rangle^{59}$.

${ }^{58}$ Memória descritiva, AUC, CAPOCUC, Pasta 275.

${ }^{59}$ Veja-se o texto completo, vindo a público pela primeira vez pela mão de Maria Aliete Galhoz na edição Obra Poética. Fernando Pessoa, organização, introdução e notas de Maria Aliete Galhoz, Rio de Janeiro, Companhia José Aguilar Editora, 1972, p. 69 (indicamos a página da edição que consultámos, a 4. ${ }^{\text {a }}$ edição; a 1. ${ }^{\text {a }}$ edição é de 1960); veja-se este texto, também, nas p. 205-206 de Mensagem e Outros Poemas Afins, introduções, organização e bibliografia actualizada de António Quadros, Mem Martins, Publicações Europa-América, 1990. Fazendo jus ao carácter gradativo tão da dilecção pessoana aquando da descrição de um método, Fernando Pessoa enumera as cinco (número muito perfeito também em matéria de simbologias) «qualidades ou condições» de que se deve munir o interpretador; estabelece entre elas hierarquias de grandeza que se vão avolumando de modo a que a última seja a mais inalcançável e, neste caso também muito curioso, a mais dificilmente apreensível por ser também ela extremamente simbólica e, inclusivamente, mistérica. 
Panofsky não aventa cinco, mas, de forma mais científica, não sem manifestação de algumas dúvidas que Pessoa também teria por resolver, apenas sugere três:

«quando nos queremos exprimir com rigor [...], temos de distinguir três níveis de conteúdo ou significado, o mais baixo dos quais se confunde geralmente com a forma e o segundo é o campo específico da iconografia em sentido estrito. Em qualquer dos níveis em que nos movamos, as nossas identificações e interpretações dependerão da nossa bagagem subjectiva e, por essa mesma razão, terão de ser corrigidas e controladas por uma grande consciência dos processos históricos que, no seu conjunto, se podem designar por tradição. [...] Quando trabalhamos, os métodos de tratamento que aqui aparecem como três formas independentes de investigação misturam-se entre si num processo orgânico e indivisível $»^{60}$;

«a interpretação do significado intrínseco ou conteúdo, que trata daquilo a que chamamos valores simbólicos e não de imagens, histórias e alegorias, requer bastante mais que o conhecimento de temas ou conceitos específicos, tal como são transmitidos pelas fontes literárias. [...] Para compreender estes princípios é necessária uma faculdade mental comparável à de fazer diagnósticos, uma faculdade que não sei descrever melhor senão usando o termo, bastante desacreditado, de intuição sintética $[\ldots]\rangle^{61}$.

Depois de propormos a leitura de Erwin Panofsky, que não tem pejo em recorrer à expressão «intuição», não resistimos a transcrever a titubeante exposição pessoana sobre «a quinta» e «menos definível» qualidade-condição do interpretador de símbolos:

«Direi talvez, falando a uns que é a graça, falando a outros que é a mão do Superior Incógnito, falando a terceiros que é o Conhecimento e Conversação do Santo Anjo da Guarda, entendendo cada uma destas coisas, que são a mesma, da maneira como as entendem aqueles que delas usam, falando ou escrevendo $»^{62}$.

Podemos, deste modo, verificar como Fernando Pessoa não caminhava distante das realidades simbólicas, como, pelo contrário, as percebia e, embora

${ }^{60}$ Erwin PANOFsky, Estudos de Iconologia. Temas humanísticos na arte do renascimento, Lisboa, Editorial Estampa, 1995, 2. ${ }^{\text {a }}$ edição, p. 28.

${ }^{61}$ Erwin PANofsky, Estudos de Iconologia ..., p. 29.

${ }^{62}$ Veja-se o excerto que tomamos do texto publicado por Maria Aliete GALHOz (organização), Obra Poética. Fernando Pessoa, supracitada, p. 69. 
não as teorizasse da mesma forma que o iconógrafo, como nelas penetrava com a mesma facilidade. Não temos dúvidas de que o poeta, à imagem de qualquer outro criador, tinha oportunidade de conviver com elas, não só quando as analisava e estudava, mas quando as criava, inserindo-as na sua obra. Quiçá até com maior facilidade de expressão, mercê da liberdade literária que possuía na formulação do pensamento sobre os símbolos e as matérias simbólicas, o poeta de "Mensagem" gozava, assim, de vantagem em relação ao cientista analisador dos símbolos pintados.

O labor de iconógrafo que aqui encetámos tentou perceber a utilização das linguagens simbólicas numa obra de literatura e numa obra de pintura que tinham o mesmo mote: fazer, através da simbologia, louvor a Portugal. Comparámos "Mensagem" e "Glorificação do Génio Português". Não seriam exactamente as mesmas intenções que moveram os criadores: os tempos da criação eram distintos e as fórmulas, inclusive as iconográficas, eram diversas, mas o substrato cultural utilizado foi, com efeito, o mesmo: ambos convocaram os mitos, os heróis, os símbolos, os signos e os sinais de uma grei para, com eles, cerzirem culto a Portugal ou, nas palavras de Fernando Pessoa, a «S. Portugal» ${ }^{63}$.

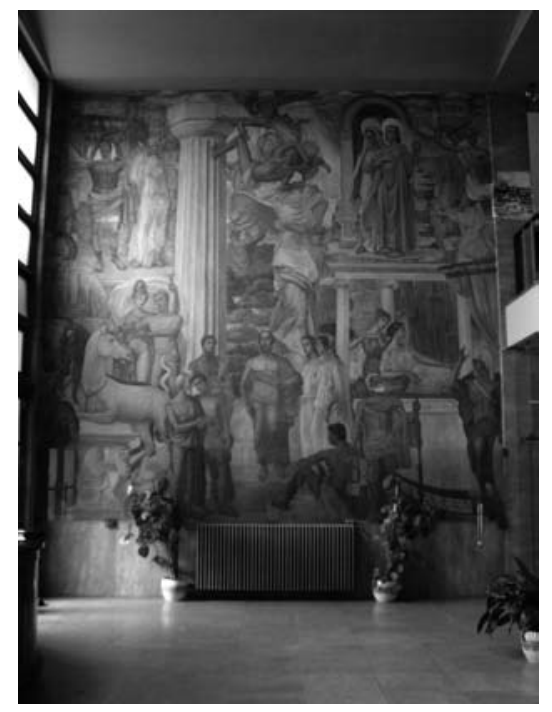

I. Os frescos da Faculdade de Letras são alegorias constituídas por figuras e símbolos conjugados com intencionalidades bem definidas: “Alegoria da Antiguidade Clássica”, Joaquim Rebocho, 1951

(fotografia de Marco Daniel Duarte)

${ }^{63}$ Antepenúltimo versículo do poema "Nuno Álvares Pereira" de Mensagem. 


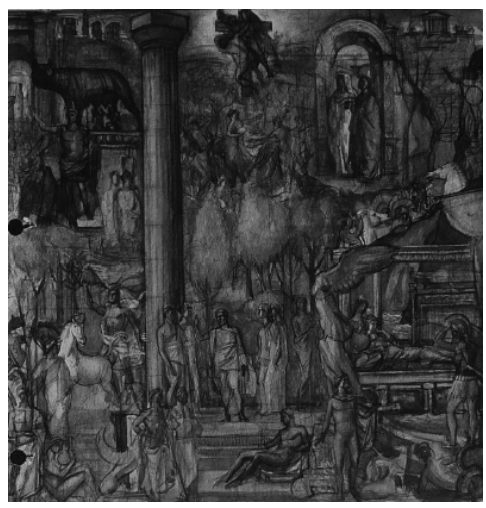

II. Esboceto com vista à elaboração da "Alegoria da Antiguidade Clássica" (Arquivo da Universidade de Coimbra)

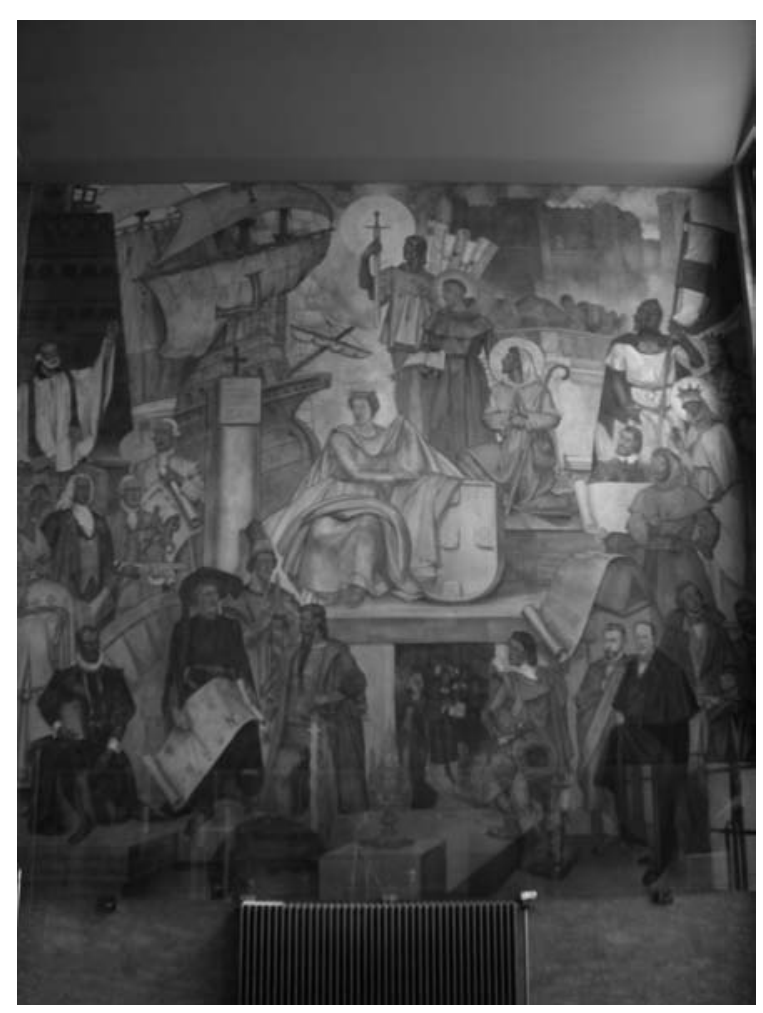

III. No fresco dedicado ao Génio da nação portuguesa, o pintor compôs um mostruário à maneira de hagiológio: “Alegoria do Génio Português”, Severo Portela Júnior, 1951 (fotografia de Marco Daniel Duarte) 


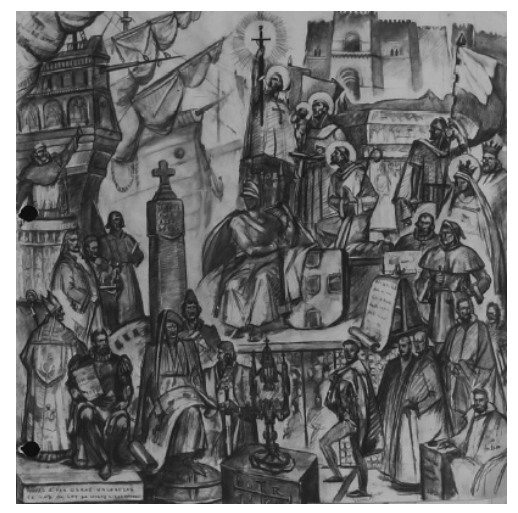

IV. Esboceto com vista à elaboração da "Alegoria do Génio Português" (Arquivo da Universidade de Coimbra)

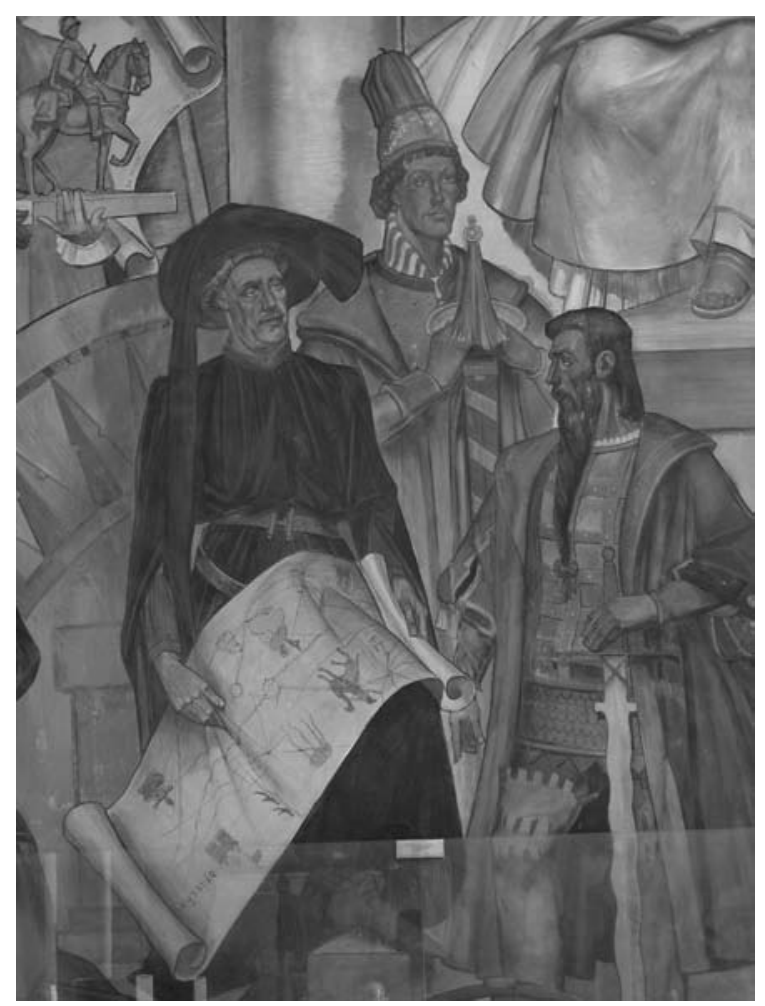

V. O infante D. Henrique, sendo, por mais que uma vez tema em "Mensagem", é um dos figurados no grupo dos homens dos Descobrimentos (fotografia de Marco Daniel Duarte) 


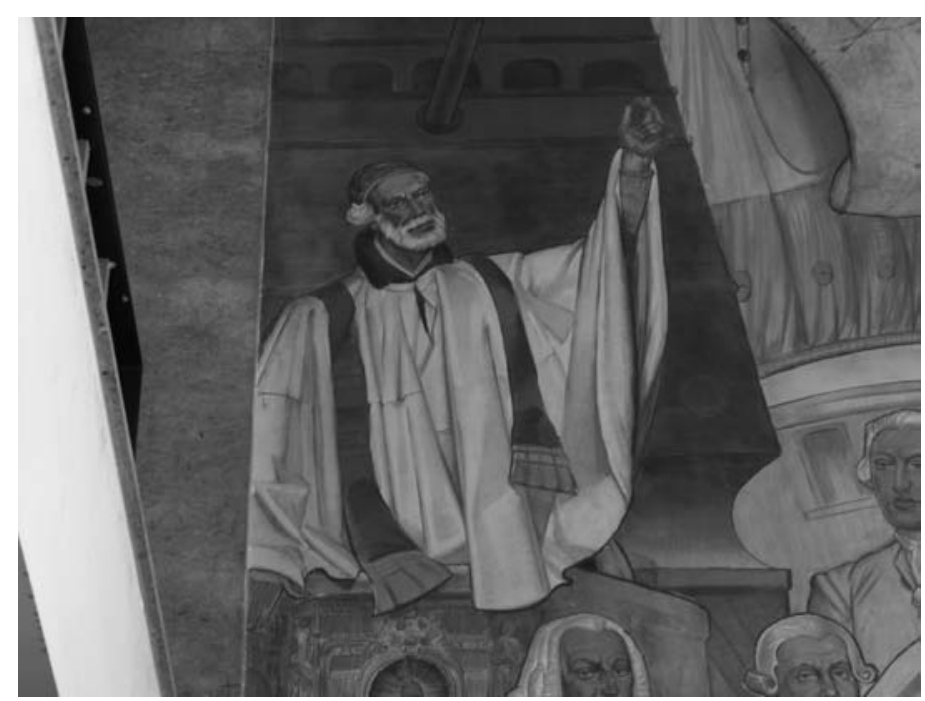

VI. Desenhado sobre o púlpito de Santa Cruz de Coimbra, tendo como fundo o cenário da Expansão, surge António Vieira, na imagem de Pessoa, «Imperador da língua portuguesa» (fotografia de Marco Daniel Duarte)

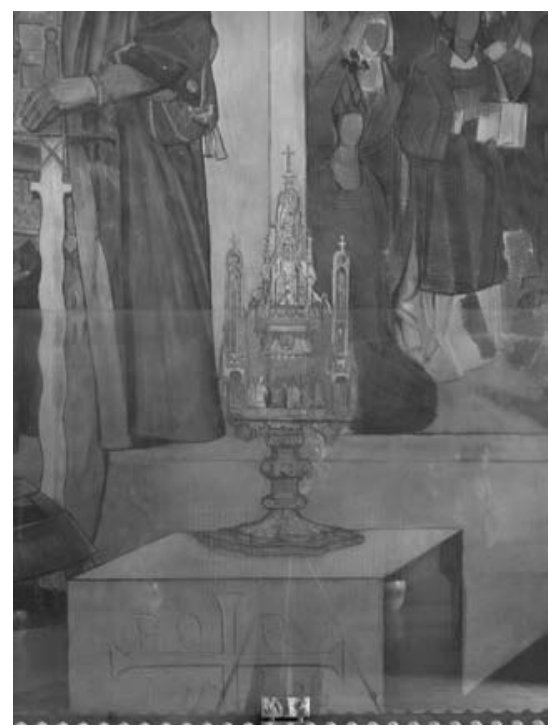

VII. O altar da pátria que o pintor figura no fundo da cena e onde inscreve a palavra "Portugal" é condensação simbólica da ambiência sacra presente na mancha pintada; ambiência comum à "Mensagem" de Pessoa cuja condensação poderá ser percebida na expressão "S. Portugal em ser" (fotografia de Marco Daniel Duarte) 